\title{
Microcystin bioaccumulation in Limnoperna fortunei following Microcystis aeruginosa exposure, analysis of in vivo enzymatic phosphatase, acetylcholinesterase and carboxylesterase effects and in vitro experiments
}

\author{
Oliveira, M.M. ${ }^{*}$, Silva, E.S. ${ }^{2}$, Calazans, S.H. ${ }^{3}$, Fernandes, F.C. ${ }^{3}$, Baeta Neves, M.H.C. ${ }^{3}$, \\ Ferrão Filho, A.S. ${ }^{4}$, Hauser Davis, R.A. ${ }^{4}$, Lopes, R.M. ${ }^{5}$, Bastos, F.F. ${ }^{2}$, \\ Cunha Bastos, V.L.F. ${ }^{2}$ \& Cunha Bastos, J. ${ }^{2}$

\begin{abstract}
${ }^{1}$ Laboratório de Ecotoxicologia e Microbiologia Ambiental - Instituto Federal Fluminense, Campus Cabo Frio, Rio de Janeiro, Brasil ${ }^{2}$ Departamento de Bioquímica - IBRAG - Universidade do Estado do Rio de Janeiro, Rio de Janeiro, Brasil

${ }^{3}$ Departamento de Oceanografia - Instituto de Estudos do Mar Almirante Paulo Moreira, Arraial do Cabo, Rio de Janeiro, Brasil ${ }^{4}$ Laboratório de Avaliação e Promoção da Saúde Ambiental - Instituto Oswaldo Cruz, FIOCRUZ, Rio de Janeiro, Brasil ${ }^{5}$ Laboratório de Comunicação Celular - Instituto Oswaldo Cruz, FIOCRUZ, Rio de Janeiro, Brasil
\end{abstract}

Received February 18, 2021; Accept September 08, 2021

\begin{abstract}
Toxic cyanobacteria blooms have been reported in freshwater sources worldwide and may lead to aquatic biota toxin accumulation and trophic chain transfer, resulting in ecological and public health concerns. To assess cyanobacteria effects on microcystin uptake and accumulation and on phosphatase, acethylcholinesterase (AChE) and carboxylesterase (CarbE) enzymatic activities, an in vivo experiment was carried out employing the golden mussel Limnoperna fortunei. These mussels were exposed to a Microcystis aeruginosa NPLJ-4 strain (NPLJ-4) for 48 hours at different cell densities. Subsequently, algal cell counts were carried out and enzymatic activities were assayed. All three enzymes (Phosphatase, AChE and CarbE) were inhibited at the end of the exposure experiment. Mussels exposed to higher in vivo M. aeruginosa densities exhibited microcystin uptake and accumulation. In vitro assays were also carried out, exposing soluble L. fortunei enzyme fractions to M. aeruginosa extracts containing microcystin, and phosphatase inhibition was observed, whereas acetylcholinesterase and carboxylesterase were not inhibited. The results indicate that metabolites other than mycrocystin probably caused the observed in vivo esterase inhibitions, requiring further investigations.
\end{abstract}

Keywords: Cyanobacteria; golden mussel; cholinesterases; carboxylesterase; microcystin

\section{INTRODUCTION}

Toxic cyanobacteria blooms have become an important environmental and public health issue in the last decades, reported in freshwater environments in over 45 countries, and in numerous brackish, coastal, and marine environments, threatening many aquatic ecosystems (Codd et al., 2005;
Paerl \& Huisman, 2008). Many toxin-producing genera, such as Microcystis, Anabaena, Anabaenopsis, Planktothrix, Aphanizomenon, Cylindrospermopsis, Raphidiopsis, and Nodularia, are able to bioaccumulate in aquatic environments (Ferrão-Filho \& Kozlowsky-Suzuki, 2011; Pham \& Utsumi, 2018). Among these genera, Microcystis is the most common bloom-forming cyanobacteria worldwide and usually 
involved in wild and domestic animals poisoning cases (Stewart et al., 2008) as well as humans (Svirčev et al., 2017). Concerning microcystin, the main cyanotoxin belonging to the Microcystis genus, although it is able to bioaccumulate in aquatic organisms, there is no evidence of biomagnification thorughout the food chain (Kozlowsky-Suzuki et al., 2012).

Some enzymes displaying important physiological and toxicological roles are affected by cyanobacterial toxins, such as phosphatase and acetylcholinesterase (AChE) (Eriksson et al., 1990; Monserrat et al., 2001). Phosphatases are intracellular enzymes that carry out the hydrolysis of phosphate groups in proteins phosphorylated by protein kinases (Cohen, 1992). Among protein phosphatases, classified as tyrosine phosphatases and serine-threonine phosphatases, two serinethreonine phosphatases are noteworthy, phosphatases 1 and 2A. Both are inhibited by cyanobacterial hepatotoxins, including microcystins (Ito et al., 2002; Mackintosh et al., 1990). Their inhibition has been associated to cytoskeleton destabilization, in combination with other effects related to cell signaling control, such as cell differentiation, growth, death (apoptosis) and tumor suppression (Mumby, 2007; Sun et al., 2014; Toivola et al., 1994; Toivola et al., 1997).

Recent studies have revealed that microcystin LR is also capable of promoting neurotoxic effects by affecting AChE (Qian et al., 2018; Wu et al., 2016). This enzyme is involved in nervous impulse transmission to muscle fibers (Massoulié et al., 1993), and is a recognized biomarker of exposure and effect of several neurotoxic compounds, such as pesticides, metals and polycyclic hydrocarbons (Brown et al., 2004; Hauser-Davis et al., 2019; Oliveira et al., 2007). Anatoxin-a (s) produced by some cyanobacteria species (for example, Anabaena spiroides) are also important acetylcholinesterase inhibitors, and of constant concern for public health organizations (Devic et al., 2002; Molica et al., 2005). In toxicokinetic studies, biotransformation (or detoxication) processes are very useful to promote a global understanding of toxicological mechanisms, also employed to assess metabolical alterations that may indicate biomarker candidates in different ecotoxicological process. Carboxylesterase (CarbE) is a phase-1 drug-metabolizing enzyme that can hydrolyze a variety of compounds, being effective in protecting against the effects of various xenobiotics (Cashman et al., 1996). As CarbE is able to hydrolyze compounds with amide bonds to promote detoxification (Satoh \& Hosokawa, 2006), its responses to microcystin exposure are important to evaluate.

Bivalves, in particular, have been reported as able to accumulate cyanotoxins at proportionally higher rates compared to other organisms, i.e., fish (Vasconcelos, 1999). Concerning microcystin, due to its low hydrophobicity, the most common process observed with refgard to cyanotoxins is biodilution $(\mathrm{BMF}<1, \mathrm{BMF}=$ biomagnification factor $)$ and not biomagnification $(\mathrm{BMF}>1)$ in the aquatic food chain (Kozlowsky-Suzuki et al., 2012, and some bivalves species have been reported as insensitive to toxic cyanobacterial effects (Martins \& Vasconcelos, 2009; Juhel et al., 2006; Vanderploeg et al., 2001), able to reproduce and survive in cyanobacterial- contaminated areas, suggesting highly successful biochemical strategies to overcome cyanobacteria toxicity (Bykova et al., 2006). Furthermore, microcystin residues have been detected larger and older mussels following toxic bloom events (Paldavičienè et al., 2015), indicating significant environmental and public health concerns, as bivalves are predated by other upper trophic level aquatic organisms and are also consumed by humans (Ferrão-Filho \& KozlowskySuzuki, 2011; Kozlowsky-Suzuki et al., 2012). In this regard, Limnoperna fortunei, an invasive bivalve mollusk recorded for the first time in South America in the early nineties (Pires et al., 2004), although not consumed by humans, exhibits high biomass and, combined with selective grazing, produces $\mathrm{N}: \mathrm{P}$ ratio alterations, increasing the incidence of cyanobacterial blooms (Boltovskoy \& Correa, 2015; Cataldo et al., 2012).

In this context, laboratory assessments regarding biochemical mussel mechanisms in the presence of cyanobacterial toxins may provide important insights on the risks of toxic blooms in mussel-colonized environments. Therefore, the aim of the present study was to assess $L$. fortune $i$ microcystin bioaccumulation and determine phosphatase and esterase activities (in vivo and in vitro) following exposure to cyanobacterial toxins.

\section{MATERIAL AND METHODS}

\section{Microcystis aeruginosa NPLJ-4 strain cultivation}

The Microcystis aeruginosa strain (NPLJ-4) used in this study was kindly provided by Dr. Sandra Azevedo (Cyanobacteria Ecophysiology and Toxicology Laboratory, Carlos Chagas Filho Biophysics Institute, UFRJ, Rio de Janeiro, Brazil), isolated from Jacarepaguá Lagoon (Rio de Janeiro, Brazil). A $3 \mathrm{~L}$ culture of this strain was grown in ASM-1 until reaching $500 \times 10^{4}$ cells $\mathrm{mL}^{-1}$, determined by counting in a Neubauer chamber.

\section{Mussel bioassay}

The Limnoperna fortune mussel specimens used herein in a semi-static in vivo assay were kindly provided by the Department of Biological Oceanography at the Instituto de Estudos do Mar Almirante Paulo Moreira (IEAPM), Arraial do Cabo, Rio de Janeiro, Brazil. A preliminary assessment was performed to determine the best algal cell concentration to promote complete mussel valve-opening, as reduced or complete valve gap closure is noted in filter-feeding bivalves exposed to very low algal concentrations (Riisgård et al., 2011), which may impair toxicity assay results.

Male and female mussels ( 15 to $25 \mathrm{~mm}$, shell length) were acclimated for $48 \mathrm{~h}$ at $25^{\circ} \mathrm{C}$ in dechlorinated freshwater, under fasting conditions in $2 \mathrm{~L}$ beakers, with water changes performed every 24 hours. $M$. aeruginosa cells were diluted to $514 \mathrm{x}$ $10^{4}, 275 \times 10^{4}, 128.5 \times 10^{4}$ and $64.25 \times 10^{4}$ cells $\mathrm{mL}^{-1}$. Three 
$2 \mathrm{~L}$ beakers were used for each $M$. aeruginosa concentration, each containing 20 mussels. The mussels were exposed to $M$. aeruginosa cells for $48 \mathrm{~h}$ at $25^{\circ} \mathrm{C}$ in dechlorinated freshwater, under a 12:12 h photoperiod and constant aeration. Nonexposed controls were maintained in the same conditions.

\section{Mussel sample processing}

After $48 \mathrm{~h}$ in the presence of algal cells, mussels were collected and soft tissues were removed and pooled $(\mathrm{n}=10$ individuals per pool, totaling five pools) for each algal concentration. Control pools were prepared in the same way. All samples were distributed into cryovials, and immediately frozen at $-20^{\circ} \mathrm{C}$.

Four pooled samples ( $\mathrm{n}=40$ individuals) were used for the enzyme assays and one $(n=10)$ was used to determine mussel microcystin concentrations. Samples were homogenized after thawing and weighing using a Potter-Elvehjem homogenizer (Potter, 1955), in a $50 \mathrm{mmol} \mathrm{L}^{-1}$ Tris-HCl, pH 7.4 buffer solution containing $250 \mathrm{mmol} \mathrm{L}^{-1}$ sucrose, $5 \mathrm{mmol} \mathrm{L}^{-1}$ EDTA, $5 \mathrm{mmol} \mathrm{L}^{-1}$ EGTA and $1 \mathrm{mmol} \mathrm{L}^{-1}$ DTT at a 1:6 mass/volume ratio (adapted from Toivola et al., 1994).

The homogenates were then centrifuged at $10,000 \mathrm{x} g$ at $4^{\circ} \mathrm{C}$ for $10 \mathrm{~min}$ in an ultracentrifuge (CP70G, Hitachi, São Paulo, Brazil) and the supernatants, hereafter termed Fraction 1 , were separated.

Soluble fractions were prepared by centrifugation for 90 $\min$ at $105,000 \times g$ at $4^{\circ} \mathrm{C}$. This soluble fraction has been reported as containing $70-80 \%$ of serine threonine protein phosphatase 1 and 2A (PP1 and PP2A) in rat liver hepatocytes (Toivola et al., 1994), thus deemed adequate for phosphatase enzyme determinations, and is also routinely applied for other enzymatic determinations.

\section{M. aeruginosa microcystin extraction}

At the end of the M. aeruginosa exponential growth phase, the culture was centrifuged at $500 \mathrm{x} g$ at $4{ }^{\circ} \mathrm{C}$ for $10 \mathrm{~min}$ using a Himac CR21 centrifuge (Hitachi, São Paulo, Brazil). The supernatants were discarded, and the pellets were freeze-dried using a Heto Drywinner freeze-dryer and stored at $-20{ }^{\circ} \mathrm{C}$ until analysis. After freeze-drying, $50 \mathrm{mg}$ were treated with $2.5 \mathrm{~mL}$ absolute methanol containing $0.1 \%$ trifluoroacetic acid (TFA), subjected to an ultrasonic bath (Thorton T7 model) at maximum frequency for $15 \mathrm{~min}$ and left to stand for 30 minutes. The extracts were then centrifuged at 500 $\mathrm{x} \mathrm{g}$ for $10 \mathrm{~min}$, the supernatants discarded and the pellets ressuspended in methanol containing $0.1 \%$ TFA. After left standing again for 30 minutes, the extracts were centrifuged again three times. The final supernatants were then collected, evaporated under a gentle $\mathrm{N}_{2}$ stream and the residues were suspended in deionized water. The solutions were then eluted through a $\mathrm{C} 18$ solid phase cartridge and extracted at various methanol concentrations. The final $100 \%$ methanol extracts were evaporated, ressuspended in $1 \mathrm{~mL}$ of deionized water and used for the in vitro exposure assays.

\section{Microcystin quantification in mussels by an Enzyme Linked Immuno Sorbent Assay (ELISA)}

Exposed mussels were freeze-dried and subjected to microcystin extractions as described above. The methanol extracts were then mixed with hexane at a 1:1 ratio. After discarding the hexane layer, the methanol was evaporated under a gentle $\mathrm{N}_{2}$ stream and the extracts ressuspended in 1 $\mathrm{mL}$ of deionized water for ELISA microcystin quantification using a commercial kit (Microcystin Plate Kit, EnviroLogix ${ }^{\circledR}$ ), according to the manufacturer's instructions. Data are expressed as microcystin-LR equivalents.

\section{Enzymatic assays - In vivo assessments - Total phosphatase (TP) activity}

TP activities were assayed according to Rivasseau et al. (1999) and Bouaïcha et al. (2002). The final reaction volume consisted in $500 \mu \mathrm{L}$, comprising $460 \mu \mathrm{L}$ of the assay buffer (Tris/ $\mathrm{HCl} 40 \mathrm{mmol} \mathrm{L}^{-1}$, $\mathrm{pH} 8.4$, containing $34 \mathrm{mmol} \mathrm{L}^{-1} \mathrm{MgCl} 2,4 \mathrm{mmol}$ $\mathrm{L}^{-1}$ EDTA and $4 \mathrm{mmol} \mathrm{L}^{-1} \mathrm{DTT}$ ) and a p-nitrophenyl phosphate liquid substrate at a final concentration of $9.8 \mathrm{mmol} \mathrm{L}^{-1}$ and $40 \mu \mathrm{L}$ of either the F1 or soluble mussel fraction. Total p-nitrophenol formation was determined by continuous kinetic readings for $90 \mathrm{~s}$ at $405 \mathrm{~nm}$ using a DU 530 spectrophotometer (Beckman, Pasadena, California). Enzyme activity was calculated using the p-nitrophenol molar absorptivity $\left(16,890 \mathrm{M}^{-1} \cdot \mathrm{cm}^{-1}\right)$. All assays were carried out in duplicate. Triplicate assays were carried out when coefficients of variation were over $10 \%$.

\section{Cholinesterase activity assays}

Cholinesterase activities were determined by Ellman's method (Ellman et al., 1961). The final reaction medium consisted in a total of $200 \mu \mathrm{L}$, comprising $160 \mu \mathrm{L}$ of a sodium phosphate $0.1 \mathrm{~mol} \mathrm{~L}^{-1}$ buffer at $\mathrm{pH} 7.5$ and $6.4 \mathrm{mmol} \mathrm{L}^{-1} \mathrm{DTNB}$ as the reaction media. The substrate (acetyltiocholine iodide) was applied at a final concentration of $1.875 \mathrm{mmol} \mathrm{L}^{-1}$. A total of $40 \mu \mathrm{L}$ of the mussel fractions were used for the three assays (F1 or soluble fraction). In all cases, product formation was determined by a continuous absorption kinetic test over $90 \mathrm{~s}$ at $412 \mathrm{~nm}$ on a UV 160A Shimadzu spectrophotometer. Enzyme activity was determined using the molar absorptivity $(14,150$ $\mathrm{M}^{-1} \mathrm{~cm}^{-1}$ ) acid of the tionitrobenzoic (TNB) formed as product. All assays were carried out in duplicate. Triplicate assays were carried out when coefficients of variation were over $10 \%$.

\section{Carboxylesterase (CarbE) activity assay}

CarbE activities were determined according to Morgan et al. (1994). The final reaction medium consisted in a total of $200 \mu \mathrm{L}$, comprising $160 \mu \mathrm{L}$ of sodium phosphate $0.1 \mathrm{~mol}$ $\mathrm{L}^{-1} \mathrm{pH} 7.7$ and p-nitrophenylacetate as substrate at a final concentration of $5 \mathrm{mmol} \mathrm{L}^{-1}$ and $40 \mu \mathrm{L}$ of the mussel fractions (F1 or soluble fraction). Total p-nitrophenol formation was determined by a continuous absorption kinetic test for $60 \mathrm{~s}$ at $400 \mathrm{~nm}$ on a Shimadzu UV-160A spectrophotometer. Enzyme activities were determined using the p-nitrophenol molar 
absorptivity $\left(13,000 \mathrm{M}^{-1} \mathrm{~cm}^{-1}\right)$. All assays were carried out in duplicate. Triplicate assays were carried out when coefficients of variation were over $10 \%$.

\section{In vitro assessments - In vitro enzymatic M. aeruginosa methanol extract effects}

All in vitro tests were carried out as described previously for phosphatase and esterases at microcystin concentrations ranging from 0.005 to $50 \mathrm{mg} \mathrm{L}^{-1}$, following incubation with methanolic extracts.

The methanolic $M$. aeruginosa extracts were incubated for 30 min with the soluble mussel fraction for IC50 determinations $\left(\mathrm{IC} 50_{30 \mathrm{~min}}\right)$. Another assay for the same extract was performed at $1 \mathrm{mg} \mathrm{L}^{-1}$ of microcystin incubated for $60 \mathrm{~min}\left(\mathrm{IC} 50_{60 \mathrm{~min}}\right.$. Controls with and without methanol were incubated under the same conditions as the extract. Phosphatase, AChE and CarbE activity assays were carried as described previously. All assays were carried out in duplicate. Triplicate assays were carried out when coefficients of variation were over $10 \%$.

\section{Eserine AChE and CarbE effects (IC50)}

Eserine, a known $\mathrm{AChE}$ cholinesterase inhibitor was employed ranging from $10^{-3}$ to $10^{-12} \mathrm{~mol} \mathrm{~L}^{-1}$ to confirm the presence of $\mathrm{AChE}$ in the soluble mussel fraction. All assays were performed as previously described for $\mathrm{AChE}$ and CarbE. After preparation, the reaction medium was left on ice for 30 min in the presence of eserine, followed by substrate addition (acetyltiocholine iodide and p-nitrophenylacetate, for $\mathrm{AChE}$ and CarbE, respectively) to begin the reaction. The controls were maintained under the same conditions but without the presence of the inhibitor. All assays were carried out in duplicate. Triplicate assays were carried out when coefficients of variation were over $10 \%$.

\section{Total protein contents}

Total protein contents were quantified by Peterson's method (Peterson, 1977) using bovine serum albumin as the external standard. This protein data is used to calculate specific enzyme activities.

\section{Statistical analyses}

All statistical analyses were carried out using the Graph Pad Prism ${ }^{\circledR}$ software. A one-way ANOVA $(p<0,05)$ was performed to assess differences between enzymatic activities at different $M$. aeruginosa algal densities and methanolic extract incubations. The $\mathrm{IC}_{50}$ results were obtained by a nonlinear regression analysis (Dose-response - Inhibition) using the Graph Pad Prism ${ }^{\circledR}$ software.

\section{RESULTS AND DISCUSSION}

The results of this study are presented categorized as: 1) ELISA microcystin bioaccumulation detection in mussels; 2)
Phosphatase and esterase enzymes (acetylcholinesterase and carboxylesterase) to verify $M$. aeruginosa exposure and toxic effects. Furthermore, complementary in vitro analyses were necessary to better characterize the analyzed enzymes, and are also presented.

\section{Cells counts and microcystin accumulation}

In general, studies carried out on bivalve mollusks and cyanobacteria are applied to determine toxin accumulation and clearance, as this information is very useful for environmental and public health risk assessments regarding potentially toxic cyanobacteria blooms (Cataldo et al., 2012; Dionisio Pires \& Van Donk, 2002; Sipiä et al., 2001; Vasconcelos et al., 2007; Willians et al., 1997).

In this experiment, the golden mussels removed considerable amounts of $M$. aeruginosa cells from the water (Table 1). However, we observed that the reduction of algal cells in the water did not correlate with toxin accumulation by toxin ingestion, since higher cell densities lead to lower ingestion rates. It is likely that higher cell densities lead to inhibition of filtering rates (Juhel et al., 2006). Morover, Microcystis sp. can be rejected in the form of pseudofeces, decreasing ingestion (Juhel et al., 2006; Gazulha et al., 2012a; Gazulha et al., 2012b).

The ELISA method detected the presence of microcystin in mussels in contact with only the higher M. aeruginosa cell

Table 1. Microcystis aeruginosa cell counts at the initial exposure time $\left(\mathrm{T}_{0}\right)$ and after $48 \mathrm{~h}\left(\mathrm{~T}_{48}\right)$ of exposure in Limnoperna fortunei.

\begin{tabular}{lccc}
\hline $\begin{array}{l}\text { Cell density } \\
\left(\text { Cells } \mathbf{~ m L}^{-1}\right)\end{array}$ & \multicolumn{2}{c}{ Cells $\mathbf{~ m L}^{-\mathbf{1}}\left(\mathbf{x} \mathbf{1 0}^{\mathbf{4}}\right)$} & \% Reduction \\
\hline $64 \times 10^{4}$ & 64 & 14 & 78.2 \\
$129 \times 10^{4}$ & 129 & 38 & 70.4 \\
$257 \times 10^{4}$ & 257 & 132 & 48.5 \\
$514 \times 10^{4}$ & 514 & 263 & 48.8 \\
\hline
\end{tabular}

To - Initial exposure time; T48 - After $48 \mathrm{~h}$ of exposure.

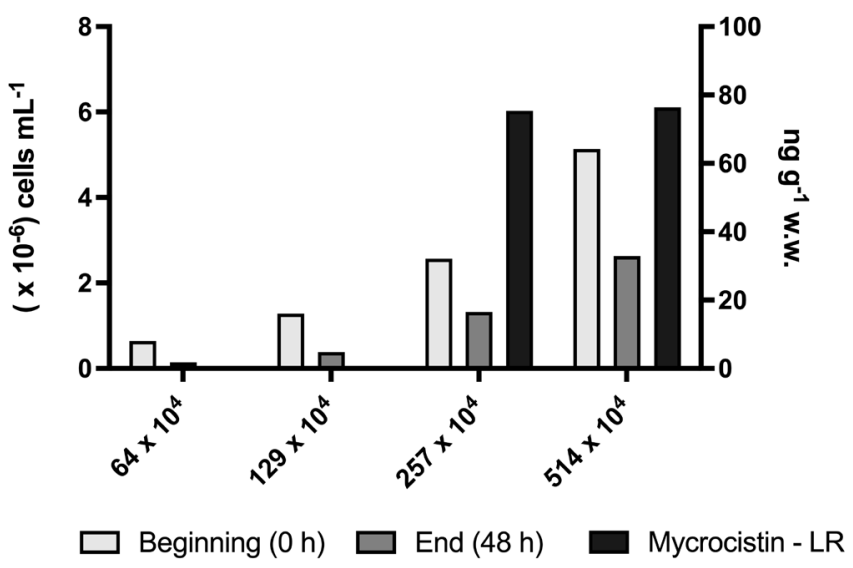

Figure 1. Cell densities and microcystin contents in L. fortunei in the presence of the M. aeruginosa NPLJ-4 strain cells. Left axis - M. aeruginosa cell density; Right Axis - L. fortunei LR microcystin content. 
densities $\left(257 \times 10^{4}\right.$ cells $\mathrm{mL}^{-1}-75.4 \mathrm{ng} \mathrm{g}^{-1}$ wet weight and $514 \times 10^{4}$ cell $\mathrm{mL}^{-1}$, or $76.5 \mathrm{ng} \mathrm{g}^{-1}$ wet weight) (Figure 1), not detected at lower cell densities exposures $\left(64 \times 10^{4}\right.$ and $129 \mathrm{x}$ $10^{4}$ cells $\left.\mathrm{mL}^{-1}\right)$. As this study did not aim to evaluate the grazing efficiency of $L$. fortunae, we cannot adequately estimate the filtration rates of different $M$. aeruginosa cell densities. However, there are no doubts concerning $M$. aeruginosa accumulation, as expected. Corroborating these data, Kim et al. (2017) reported that three bivalve mollusk species exposed to M. aeruginosa bloom accumulated microcystins in their digestive glands and muscle tissue, presenting different clearance and detoxification systems.

Another relevant aspect concerning L. fortunei refers to its inability to distinguish between microcystin-producing and non-producing $M$. aeruginosa cells, which reinforces the fact that the species is an important vehicle for microcystin transfer throughout the trophic chain (Gazulha et al., 2012a; Von Ruckert et al., 2004). Another mussel species, Dreissena polymorpha, has been reported as able to distinguish between toxic and non-toxic $M$. aeruginosa cells in laboratory experiments (Dionizio Pires \& Van Donk, 2002; Vanderploeg et al., 2001).According to Martins and Vasconcelos (2009), although both freshwater and marine mussels can accumulate cyanotoxins during toxic cyanobacteria blooms, this accumulation pattern depends on the species. Interspecific differences can be caused by food intake selection, reproductive period, microcystin metabolism and clearance rate (Martins \& Vasconcelos, 2009).

\section{Enzymatic assays following in vivo L. fortunei exposure to M. aeruginosa}

These enzymatic assays were performed after 48 hours of exposure of $L$. fortunei to $M$. aeruginosa and reflect the toxicological biochemical condition of the specimens concerning three enzymatic parameters: phosphatase (microcystin inhibition), CarbE (phase 1 biotransformation) and $\mathrm{AChE}$ (neurotoxic exposure).The enzymatic assay results after $M$. aeruginosa mussel exposure are displayed in Figure 2. All M. aeruginosa cell density mussel exposures led to phosphatase activity inhibition in the F1 mussel fraction, reaching about a $90 \%$ decrease, while about $50 \%$ activity inhibitions were observed at all cell densities for both CarbE and $\mathrm{AChE}$ (Figure 2).

Total phosphatase inhibition was observed in L. fortunei exposed to M. aeruginosa, as reported in other studies. For example, a significant reduction in PP2A activity with a concomitant enhancement of its gene expression in the freshwater clam Corbicula fluminea has been reported after exposure for $96 \mathrm{~h}$ to $5 \mu \mathrm{g} . \mathrm{L}^{-1}$ of dissolved microcystin-LR (Martins et al., 2011). On the other hand, another freshwater mussel Dreissena polymorpha exposed to $100 \mu \mathrm{g} \mathrm{\textrm {L } ^ { - 1 }}$ microcystin-LR for up to $72 \mathrm{~h}$ exhibited no alteration in protein phosphatase 2A (PP2A) gene expression (ContardoJara et al., 2008).

The CarbE inhibition observed herein is indicative of a carboxylesterase inhibitor present in the employed $M$. aeruginosa NPLJ-4 strain. In this regard, a cell culture (HEK293-OATP1B3 cells) exposed to microcystin-LR displayed increased CarbE gene expression, attenuating the cytotoxicity of the microcystin strain (Takumi et al., 2017). As an enzyme related to the detoxification of various xenobiotics, such as organophosphates, pyrethroids and drugs (Whellock et al., 2008), CarbE inhibition may indicate a toxicokinetic flow of toxic metabolites from M. aeruginosa. To the best of our knowledge, this is the first record of cyanobacterial metabolites effects on shellfish CarbE. AChE activities were lower at all algal densities, indicating the presence of a cholinergic inhibitor in the M. aeruginosa NPLJ-4 strain. This corroborates other reports, such as the study carried out by Kankaanpää (2007) concerning Mytilus edulis exposed to Nodularia spumigena cyanobacteria. AChE inhibition was also reported in Macoma balthica specimens exposed to the cyanobacterium Nodularia spumigena, which produces the hepatotoxin nodularin, at $20 \mathrm{mg}$ dry weight $\mathrm{L}^{-1}$ after a $96 \mathrm{~h}$ assay (Lehtonen et al., 2003). In addition, some cyanobacteria species belonging to the Anabaena genus produce anatoxina(s), a known AChE inhibitor (Molica et al., 2005; Matsunaga et al., 1989). However, anatoxin-a (s) was not assessed in
A

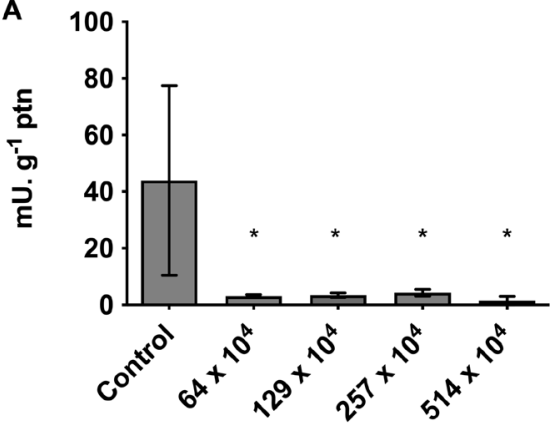

Cells $\mathrm{mL}^{-1}$

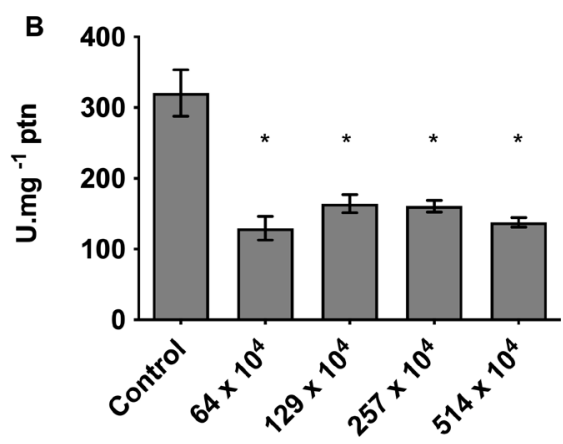

Cells $\mathrm{mL}^{-1}$

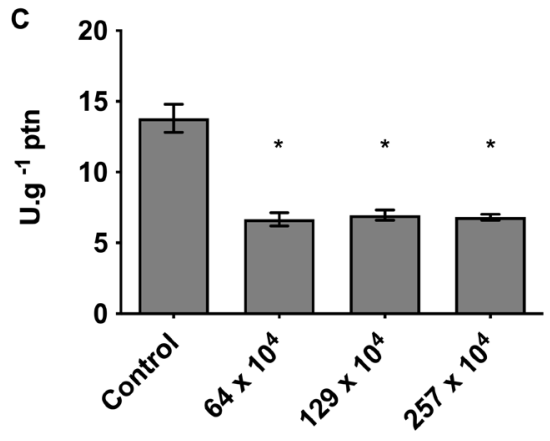

Cells $\mathrm{mL}^{-1}$

Figure 2. (A) Phosphatase, (B) CarbE and (C) AChE activities in the F1 fraction after 48 h of exposure to $M$. aeruginosa. * indicates significant differences between means by the ANOVA $(\mathrm{p}<0.05)$. Tukey's test indicated difference among all enzyme activities at different cell densities compared to the controls. 
the present study, as the NPLJ-4 strain is a microcystin-LR producer (Silva-Stenico et al., 2009).

\section{Enzymatic assays concerning in vitro L. fortunei exposure to M. aeruginosa extracts and eserine}

The use of inhibitors is a valuable tool to identify an enzyme or group of enzymes, especially when obtained from a crude extract, non-purified enzyme (Copeland 2000). Therefore, the following tests were used to briefly characterize the afore mentioned enzymes.

As a way of verifying whether the methanolic extract rich in microcystin-LR would be able to inhibit the L. fortunai enzymes evaluated herein in vitro, samples were incubated as described in the material and methods section. After $1 \mathrm{~h}$ of incubation at $1 \mathrm{mg} \mathrm{L}^{-1}$ microcystin, $48 \%$ of the soluble fraction phosphatase activity was inhibited. No AChE or CarbE inhibition was observed, even after $1 \mathrm{~h}$ of incubation with the methanolic extract (Table 2). An inhibition curve was also constructed for $L$. fortunai phosphatase, in order to obtain the phosphatase IC $50_{30 \mathrm{~min}}$, determined as $3.5 \mathrm{nmol}$ $\mathrm{L}^{-1}$ microcystin.

Phosphatases were significantly inhibited by the $M$. aeruginosa extracts, justifying the high percentage of phosphatase activity inhibition obtained in the in vivo experiment. Rivas et al. (2000) also reported Mytilus chilensis phosphatase inhibition by microcystin-LR in an in vitro study conducted with purified enzymes and cyanotoxin, where the inhibition was more toxic than that of other phycotoxins (ocadaic acid and dinophysistoxin). As expected, the in vitro results with the $M$. aeruginosa extracts gave no indication that microcystins are involved in the observed in vivo esterase inhibition. Thus, bioactive cyanobacteria compounds other than microcystins may explain the inhibition results for the other evaluated enzymes, requiring further studies.

Eserine (physostigmine) is an alkaloid extracted from calabar beans, considered a strong reversible cholinesterase inhibitor (Batiha et al., 2020). The concentration able to inhibit $50 \%$ of enzyme activity in $30 \mathrm{~min}\left(\mathrm{IC} 50_{30 \mathrm{mi}} \mathrm{n}\right)$ was of $5.53 \times 10^{-3} \mathrm{mmol} \mathrm{L}^{-1}$ for AChE and $5.17 \times 10^{-3} \mathrm{mmol} \mathrm{L}^{-1}$ for CarbE. The IC-50 determination for esterases using eserine aimed to identify golden mussel esterase similarities to other aquatic organisms, and the values obtained herein indicate that the analyzed L. fortunei cholinesterase, probably AChE, is similar to those observed in other mollusks. Eserine data from the present study are compared to other reports in the literature for bivalves, displayed in Table 3 .

Table 2 - Inhibitory effect of $M$. aeruginos $a$ extracts on acetylcholinesterase (AChE), Total phosphatase (TP) and Carboxylesterase (CarbE) activities in soluble $L$. fortunei fractions.

\begin{tabular}{lc} 
Enzyme & Enzyme activity inhibition (\%) \\
\hline TP & 48 \\
AChE & 0 \\
CarbE & 0 \\
\hline
\end{tabular}

The phosphatase results were similar in both the in vivo and in vitro experiments. However, esterase (AChE and CarbE) in vivo inhibition was not confirmed by the in vitro experiment. This has is an interesting field of study in microcystin ecotoxicology, as the recognition that microcystin can accumulate in the brain has led to several assessments aiming to better understand its neurotoxicity (Hinojosa et al., 2019; Yu et al., 2021; Wang et al., 2010). In fact, in vivo studies carried out with another mollusc, Macoma balthica, indicated significant $\mathrm{AChE}$ activity inhibition following exposure to $50 \mu \mathrm{g} \mathrm{L}^{-1}$ nodularin, also a hepatoxin, and $20 \mathrm{mg} \mathrm{L}^{-1}$ of Nodularia spumigena. A slight increase in activity, albeit non-significant, was observed at lower doses of both nodularin and Nodularia spumigena (Lehtonen et al., 2003). In fish, Danio rerio exposed to an acute microcystin concentration in water $\left(100 \mu \mathrm{g} \mathrm{L}^{-1}\right)$ demonstrated an increase in the activity and transcription of AChE mRNA (Kist et al., 2012). Increased AChE activity was also verified in another experiment following Geophagus brasiliensis exposure to sublethal microcystin concentration of $1 \mu \mathrm{g} \mathrm{L}^{-1}$ during a clearance period (Calado et al., 2019).

No conclusive responses concerning the integrated relationship between $L$. fortunei bioaccumulation results and the observed biochemical responses were observed herein. However, our study demonstrated the ability of this species to consume $M$. aeruginosa cells followed by efficient clearance, also indicating accumulation without leading to death. The investigated enzymes were rapidly inhibited, although this does not appear to be dose dependent. Subsequent studies include investigations on Glutathione (GSH) concentrations and Glutathione S-tranferase (GST) activities, as a way to verify the main microcystin biotransformation or detoxification main process in this bivalve (Amado et al., 2011).

\section{CONCLUSIONS}

The golden mussel L. fortunai is an invasive species in Brazilian aquatic environments and displays a high capacity to accumulate microcystins during cyanobacterial blooms, enabling the transfer of this toxin to other trophic levels, although scarce knowledge on the biochemical behavior of this mussel following microcystins exposure is available. Herein, phosphatases, a common toxicodynamic microcystin target, were significantly affected, although not enough to cause $L$. fortunei death. Acetylcholinesterase and carboxylesterase

Table 3. In vitro enzymatic activity inhibition ( $\mathrm{IC}_{30} \mathrm{~m}_{30 \text { min }}$ eserine) for $\mathrm{AChE}$

\begin{tabular}{lcc}
\hline Organism & $\begin{array}{c}\text { AChE } \\
(\mathbf{m m o l ~ L}\end{array}$ & Reference \\
\hline Limnoperna fortunei & $5.53 \times 10^{-3}$ & Present study \\
Potamopyrgus antipodarum & $0.034 \times 10^{-3}$ & Gagnaire et al. $(2008)$ \\
Valvata piscinalis & $1.39 \times 10^{-3}$ & Gagnaire et al. $(2008)$ \\
Ostrea edulis & $1.04 \times 10^{-4}$ & Valbonesi et al. $(2003)$ \\
Mytilus galloprovincialis & $2.06 \times 10^{-5}$ & Valbonesi et al. $(2003)$ \\
Mytilus edulis & $<0.01$ & Galloway et al. $(2002)$ \\
\hline
\end{tabular}


were also inhibited, although probably due to compounds other than the assessed microcystin, may according to the in vitro findings reported herein. Therefore, further studies should be conducted to investigate which metabolite is responsible for these inhibitions.

\section{REFERENCES}

AMADO, L. L., GARCIA, M. L., RAMOS, P. B., YUNES, J. S., \& MONSERRAT, J. M. 2011. Influence of a toxic Microcystis aeruginosa strain on glutathione synthesis and glutathione-Stransferase activity in common carp Cyprinus carpio (Teleostei: Cyprinidae). Arch. Environ. Contam., 60(2), 319-326. https:// doi.org/10.1007/s00244-010-9594-2

BATIHA, G. E. S., ALKAZMI, L. M., NADWA, E. H., RASHWAN, E. K., BESHBISHY, A. M., SHAHEEN, H., \& WASEF, L. 2020. Physostigmine: A plant alkaloid isolated from Physostigma venenosum: A review on pharmacokinetics, pharmacological and toxicological activities. J. drug deliv. ther., 10(1-s), 187-190. https://doi.org/10.22270/jddt.v10i1-s.3866

BOLTOVSKOY, D., \& CORREA, N. 2015. Ecosystem impacts of the invasive bivalve Limnoperna fortunei (golden mussel) in South America. Hydrobiologia, 746(1), 81-95. https://doi. org/10.1007/s10750-014-1882-9

BOUAICHA, N., MAATOUK, I., VINCENT, G., \& LEVI, Y. 2002. A colorimetric and fluorometric microplate assay for the detection of microcystin-LR in drinking water without preconcentration. Food Chem. Toxicol., 40(11), 1677-1683. https://doi.org/10.1016/S0278-6915(02)00103-5

BROWN, M., DAVIES, I. M., MOFFAT, C. F., REDSHAW, J., \& CRAFT, J. A. 2004. Characterisation of choline esterases and their tissue and subcellular distribution in mussel (Mytilus edulis). Mar. Environ. Res., 57(3), 155-169. https://doi. org/10.1016/S0141-1136(03)00067-9

BYKOVA, O., LAURSEN, A., BOSTAN, V., BAUTISTA, J., \& MCCARTHY, L. 2006. Do zebra mussels (Dreissena polymorpha) alter lake water chemistry in a way that favours Microcystis growth?. Sci. Total Environ., 371(1-3), 362-372. https://doi.org/10.1016/j.scitotenv.2006.08.022

CALADO, S. L.M., VICENTINI, M., SANTOS, G. S., PELANDA, A., SANTOS, H., CORAL, L. A., ... \& DE ASSIS, H. C. S. 2019. Sublethal effects of microcystin-LR in the exposure and depuration time in a neotropical fish: Multibiomarker approach. Ecotoxicol. Environ. Saf., 183, 109527. https://doi.org/10.1016/j. chemosphere.2019.124616

CASHMAN, J. R., PEROTTI, B. Y., BERKMAN, C. E., \& LIN, J. 1996. Pharmacokinetics and molecular detoxication. Environ. Health Perspect., 104(suppl 1), 23-40. https://doi.org/10.1289/ ehp. 96104 s 123

CATALDO, D., VINOCUR, A., INÉS, O., PAOLUCCI, E., LEITES, V., \& BOLTOVSKOY, D. 2012. The introduced bivalve Limnoperna fortunei boosts Microcystis growth in Salto Grande reservoir (Argentina): evidence from mesocosm experiments. Hydrobiologia, 680(1), 25-38. https://doi.org/10.1007/s10750011-0897-8

CODD, G. A., MORRISON, L. F., \& METCALF, J. S. 2005. Cyanobacterial toxins: risk management for health protection. Toxicol Appl Pharmacol, 203(3), 264-272. https://doi. org/10.1016/j.taap.2004.02.016

COHEN, P., 1992. Signal integration at the level of protein kinases, protein phosphatases and their substrates. Trends Biochem. Sci. 17, 408-413. https://doi.org/10.1016/0968-0004(92)90010-7

CONTARDO-JARA, V., PFLUGMACHER, S., \& WIEGAND, C.
2008. Multi-xenobiotic-resistance a possible explanation for the insensitivity of bivalves towards cyanobacterial toxins. Toxicon, 52(8), 936-943. https://doi.org/10.1016/j.toxicon.2008.09.005

COPELAND, R. A. 2000. Enzymes: a practical introduction to structure, mechanism, and data analysis. John Wiley \& Sons.

DEVIC, E., LI, D., DAUTA, A., HENRIKSEN, P., CODD, G. A., MARTY, J. L., \& FOURNIER, D. 2002. Detection of anatoxin-a (s) in environmental samples of cyanobacteria by using a biosensor with engineered acetylcholinesterases. Appl. Environ. Microbiol, 68(8), 4102-4106. https://doi.org/10.1128/ AEM.68.8.4102-4106.2002

DIONISIO PIRES, L. M., \& VAN DONK, E. 2002. Comparing grazing by Dreissena polymorpha on phytoplankton in the presence of toxic and non-toxic cyanobacteria. Freshw. Biol., 47(10), 1855-1865. https://doi.org/10.1046/j.13652427.2002.00933.x

ELlMAN, G. L., COURTNEY, K. D., ANDRES JR, V., \& FEATHERSTONE, R. M. (1961). A new and rapid colorimetric determination of acetylcholinesterase activity. Biochem. Pharmacol., 7(2), 88-95. https://doi.org/10.1016/00062952(61)90145-9

ERIKSSON, J. E., TOIVOLA, D., MERILUOTO, J. A. O., KARAKI, H., HAN, Y. G., \& HARTSHORNE, D. 1990. Hepatocyte deformation induced by cyanobacterial toxins reflects inhibition of protein phosphatases. Biochem. Biophys. Res. Commun., 173(3), 1347-1353. https://doi.org/10.1016/ S0006-291X(05)80936-2

FERRÃO-FILHO, A. D. S., \& KOZLOWSKY-SUZUKI, B. 2011. Cyanotoxins: bioaccumulation and effects on aquatic animals. Mar. Drugs, 9(12), 2729-2772. https://doi.org/10.3390/ md9122729

GAGNAIRE, B., GEFFARD, O., XUEREB, B., MARGOUM, C., \& GARRIC, J. (2008). Cholinesterase activities as potential biomarkers: characterization in two freshwater snails, Potamopyrgus antipodarum (Mollusca, Hydrobiidae, Smith 1889) and Valvata piscinalis (Mollusca, Valvatidae, Müller 1774). Chemosphere, 71(3), 553-560. https://doi.org/10.1016/j. chemosphere.2007.09.048

GALlOWAY, T. S., MILLWARD, N., BROWNE, M. A., \& DEPLEDGE, M. H. (2002). Rapid assessment of organophosphorous/carbamate exposure in the bivalve mollusc Mytilus edulis using combined esterase activities as biomarkers. Aquat. Toxicol., 61(3-4), 169-180. https://doi.org/10.1016/ S0166-445X(02)00051-6

GAZULHA, V., MANSUR, M. C. D., CYBIS, L. F., \& AZEVEDO, S. M. F. O. 2012a. Feeding behavior of the invasive bivalve Limnoperna fortunei (Dunker, 1857) under exposure to toxic cyanobacteria Microcystis aeruginosa. Braz. J. Biol, 72(1), 4149. https://dx.doi.org/10.1590/S1519-69842012000100005

GAZULHA, V., MANSUR, M. C. D., CYBIS, L. F., \& AZEVEDO, S. M. F. O. 2012b. Grazing impacts of the invasive bivalve Limnoperna fortunei (Dunker, 1857) on single-celled, colonial and filamentous cyanobacteria. Braz. J. Biol. 72, 33-39. http:// dx.doi.org/10.1590/S1519-69842012000100004

HAUSER-DAVIS, R. A., LOPES, R. M., \& ZIOLLI, R. L. 2019. Inihibition of mullet (M. liza) brain acetylcholinesterase activity by in vitro polycyclic aromatic hydrocarbon exposure. Mar. Pollut. Bull., 140, 30-34. https://doi.org/10.1016/j. marpolbul.2019.01.027

HINOJOSA, M. G., GUTIÉRREZ-PRAENA, D., PRIETO, A. I., GUZMÁN-GUILLÉN, R., JOS, A., \& CAMEAN, A. M. 2019. Neurotoxicity induced by microcystins and cylindrospermopsin: A review. Sci. Total Environ., 668, 547-565. https://doi. org/10.1016/j.scitotenv.2019.02.426 
ITO, E., TAKAI, A., KONDO, F., MASUI, H., IMANISHI, S., \& HARADA, K. I. 2002. Comparison of protein phosphatase inhibitory activity and apparent toxicity of microcystins and related compounds. Toxicon, 40(7), 1017-1025. https://doi. org/10.1016/S0041-0101(02)00099-5

JUHEL, G., DAVENPORT, J., O'HALLORAN, J., CULLOTY, S., RAMSAY, R., JAMES, K., ... \& ALLIS, O. 2006. Pseudodiarrhoea in zebra mussels Dreissena polymorpha (Pallas) exposed to microcystins. J. Exp. Biol., 209(5), 810-816. https:// doi.org/10.1242/jeb.02081

KANKAANPÄÄ, H., LEINIÖ, S., OLIN, M., SJÖVALL，O., MERILUOTO, J., \& LEHTONEN, K. K. 2007. Accumulation and depuration of cyanobacterial toxin nodularin and biomarker responses in the mussel Mytilus edulis. Chemosphere, 68(7), 1210-1217. https://doi.org/10.1016/j.chemosphere.2007.01.076

KIM, M. S., LEE, Y. J., HA, S. Y., KIM, B. H., HWANG, S. J., KWON, J. T., ... \& SHIN, K. H. 2017. Accumulation of microcystin (LR, RR and YR) in three freshwater bivalves in Microcystis aeruginosa bloom using dual isotope tracer. Mar. Drugs, 15(7), 226. https://doi.org/10.3390/md15070226

KIST, L. W., ROSEMBERG, D. B., PEREIRA, T. C. B., DE AZEVEDO, M. B., RICHETTI, S. K., DE CASTRO LEÃO, J., ... \& BOGO, M. R. 2012. Microcystin-LR acute exposure increases AChE activity via transcriptional ache activation in zebrafish (Danio rerio) brain. Comp. Biochem. Physiol. Part - C: Toxicol. Pharmacol., 155(2), 247-252. https://doi.org/10.1016/j. cbpc.2011.09.002

KOZLOWSKY-SUZUKI, B., WILSON, A. E., \& DA SILVA FERRAO-FILHO, A. 2012. Biomagnification or biodilution of microcystins in aquatic foodwebs? Meta-analyses of laboratory and field studies. Harmful Algae, 18, 47-55. https://doi. org/10.1016/j.hal.2012.04.002

LEHTONEN, K. K., KANKAANPÄÄ, H., LEINIÖ, S., SIPIÄ, V. O., PFLUGMACHER, S., \& SANDBERG-KILPI, E. 2003. Accumulation of nodularin-like compounds from the cyanobacterium Nodularia spumigena and changes in acetylcholinesterase activity in the clam Macoma balthica during short-term laboratory exposure. Aquat. Toxicol., 64(4), 461-476. https://doi.org/10.1016/S0166-445X(03)00101-2

MACKINTOSH, C., BEATTIE, K. A., KLUMPP, S., COHEN, P., \& CODD, G. A. 1990. Cyanobacterial microcystin-LR is a potent and specific inhibitor of protein phosphatases 1 and $2 \mathrm{~A}$ from both mammals and higher plants. FEBS letters, 264(2), 187-192. https://doi.org/10.1016/0014-5793(90)80245-e.

MARTINS, J. C., \& VASCONCELOS, V. M. 2009. Microcystin dynamics in aquatic organisms. J. Toxicol. Environ. Health - B: Crit. Rev., 12(1), 65-82. https://doi. org/10.1080/10937400802545151

MARTINS, J. C., MACHADO, J., MARTINS, A., AZEVEDO, J., OLIVATELES, L., \& VASCONCELOS, V. 2011. Dynamics of protein phosphatase gene expression in Corbicula fluminea exposed to microcystin-LR and to toxic Microcystis aeruginosa cells. Int. J. Mol. Sci., 12(12), 9172-9188. https://doi. org/10.3390/ijms 12129172

MASSOULIÉ, J., PEZZEMENTI, L., BON, S., KREJCI, E., VALLETTE, F.M. 1993. Molecular and cellular biology of cholinesterases. Prog. Neurobiol. 41: 31-91. https://doi. org/10.1016/0301-0082(93)90040-Y

MATSUNAGA, S., MOORE, R. E., NIEMCZURA, W. P., \& CARMICHAEL, W. W. 1989. Anatoxin-a (s), a potent anticholinesterase from Anabaena flos-aquae. J. Am. Chem. Soc., 111(20), 8021-8023. https://doi.org/10.1021/ja00202a057

MOLICA, R. J., OLIVEIRA, E. J., CARVALHO, P. V., COSTA, A. N., CUNHA, M. C., MELO, G. L., \& AZEVEDO, S. M.
2005. Occurrence of saxitoxins and an anatoxin-a (s)-like anticholinesterase in a Brazilian drinking water supply. Harmful algae, 4(4), 743-753. https://doi.org/10.1016/j.hal.2004.11.001

MONSERRAT, J. M., YUNES, J. S., \& BIANCHINI, A. 2001. Effects of Anabaena spiroides (Cyanobacteria) aqueous extracts on the acetylcholinesterase activity of aquatic species. Environ. Toxicol. Chem., 20(6), 1228-1235. https://doi.org/10.1002/ etc.5620200611

MORGAN, E. W., YAN, B., GREENWAY, D., PETERSEN, D. R., PARKINSON, A. 1994 Purification and characterization of two rat liver microsomal carboxylesterases (hydrolase A and B). Arch. Biochem. Biophys. 315, 495-512. https://doi.org/10.1006/ abbi.1994.1531

MUMBY, M. 2007. PP2A: unveiling a reluctant tumor suppressor. Cell, 130(1), 21-24. https://doi.org/10.1016/j.cell.2007.06.034

OLIVEIRA, M. M., SILVA FILHO, M. V., BASTOS, V. L. C., FERNANDES, F. C., \& BASTOS, J. C. 2007. Brain acetylcholinesterase as a marine pesticide biomarker using Brazilian fishes. Mar. Environ. Res., 63(4), 303-312. https://doi. org/10.1016/j.marenvres.2006.10.002

PAERL, H. W., HUISMAN, J., 2008. Blooms like it hot. Science. 320, 57-58. https://doi.org/10.1126/science. 1155398

PALDAVIČIENĖ, A., ZAIKO, A., MAZUR-MARZEC, H., \& RAZINKOVAS-BAZIUKAS, A. 2015. Bioaccumulation of microcystins in invasive bivalves: a case study from the boreal lagoon ecosystem. Oceanologia, 57(1), 93-101. https://doi. org/10.1016/j.oceano.2014.10.001

PETERSON, G. L., 1977. A simplification of the protein assay method of Lowry et al. which is more generally applicable. Anal. Biochem.. 83, 346-356. https://doi.org/10.1016/00032697(77)90043-4

PFLUGMACHER, S., WIEGAND, C., OBEREMM, A., BEATTIE, K. A., KRAUSE, E., CODD, G. A., \& STEINBERG, C. E. 1998. Identification of an enzymatically formed glutathione conjugate of the cyanobacterial hepatotoxin microcystin-LR: the first step of detoxication. Biochim. Biophys. Acta - Gen. Subj., 1425(3), 527-533. https://doi.org/10.1016/S0304-4165(98)00107-X

PHAM, T. L., \& UTSUMI, M. 2018. An overview of the accumulation of microcystins in aquatic ecosystems. J. Environ. Manage. , 213, 520-529. https://doi.org/10.1016/j.jenvman.2018.01.077

PIRES, L. D., KARlSSON, K. M., MERILUOTO, J. A. O., KARDINAAL, E., VISSER, P. M., SIEWERTSEN, K., ... \& IBELINGS, B. W. 2004. Assimilation and depuration of microcystin-LR by the zebra mussel, Dreissena polymorpha. Aquat. Toxicol., 69(4), 385-396. https://doi.org/10.1016/j. aquatox.2004.06.004

POTTER, V.R. 1955. Tissue Homogenates. In: S.P. Colowick and N.O. Kaplan (ed.). Methods Enzymol. 1:10-15. https://doi. org/10.1016/0076-6879(55)01006-9

QIAN, H., LIU, G., LU, T., \& SUN, L. 2018. Developmental neurotoxicity of Microcystis aeruginosa in the early life stages of zebrafish. Ecotoxicol. Environ. Saf., 151, 35-41. https://doi. org/10.1016/j.ecoenv.2017.12.059

RIISGÅRD, H. U., EGEDE, P. P., \& BARREIRO SAAVEDRA, I. 2011. Feeding behaviour of the mussel, Mytilus edulis: new observations, with a minireview of current knowledge. J. Mar. Biol.. https://doi.org/10.1155/2011/312459

RIVAS, MARIELLA, GARCÍA, CARLOS, LIBERONA, JOSÉ L, \& LAGOS, NÉSTOR. (2000). Biochemical characterization and inhibitory effects of dinophysistoxin-1, okadaic acid and microcystine 1-r on protein phosphatase 2a purified from the mussel Mytilus chilensis.. Biol. Res., 33(3-4), 197-206. https:// dx.doi.org/10.4067/S0716-97602000000300005

RIVASSEAU, C., RACAUD, P., DEGUIN, A., \& HENNION, M. 
C. 1999. Development of a bioanalytical phosphatase inhibition test for the monitoring of microcystins in environmental water samples. Anal. Chim. Acta, 394(2-3), 243-257. https://doi. org/10.1016/S0003-2670(99)00301-3

SATOH, T., \& HOSOKAWA, M. 2006. Structure, function and regulation of carboxylesterases. Chem.-Biol. Interact., 162(3), 195-211. https://doi.org/10.1016/j.cbi.2006.07.001

SILVA-STENICO, MARIA ESTELA, CANTÚSIO NETO, ROMEU, ALVES, IVÂNIO R., MORAES, LUIZ ALBERTO B., SHISHIDO, TÂNIA K., \& FIORE, MARLI FÁTIMA. 2009. Hepatotoxin microcystin-LR extraction optimization.J. Braz. Chem. Soc., 20(3), 535-542. https://doi.org/10.1590/S010350532009000300019

SIPIÄ, V. O., KANKAANPÄÄ, H. T., FLINKMAN, J., LAHTI, K., \& MERILUOTO, J. A. 2001. Time-dependent accumulation of cyanobacterial hepatotoxins in flounders (Platichthys flesus) and mussels (Mytilus edulis) from the northern Baltic Sea.

Environ. Toxicol., 16(4), 330-336. https://doi.org/10.1002/ tox. 1040

STEWART, I., SEAWRIGHT, A.A., SHAW, G.R. 2008. Cyanobacterial poisoning in livestock, wild mammals and birds - An overview. In: Cyanobacterial Harmful Algal Blooms: State of the Science and Research Needs; Hudnell, H.K., Ed.; Springer Science: New York, NY, USA, Volume 619, Chapter 28, pp. 613-637.

SVIRČEV,Z., DROBAC, D., TOKODI, N., MIJOVIC, B., CODD, G.A., MERILUOTO, J. 2017. Toxicology of microcystins with reference to cases of human intoxications and epidemiological investigations of exposures to cyanobacteria and cyanotoxins. Arch. Toxicol. 91:621-650.

SUN, Y., ZHENG, Q., SUN, Y. T., HUANG, P., GUO, Z. L., \& XU, L. H. 2014. Microcystin-LR induces protein phosphatase $2 \mathrm{~A}$ alteration in a human liver cell line. Environ. Toxicol., 29(11), 1236-1244. https://doi.org/10.1002/tox.21854

TAKUMI, S., SHIMONO, T., IKEMA, S., HOTTA, Y., CHIGWECHOKHA, P. K., SHIOZAKI, K., ... \& KOMATSU, M. 2017. Overexpression of carboxylesterase contributes to the attenuation of cyanotoxin microcystin-LR toxicity. Comp. Biochem. Physiol. Part - C: Toxicol. Pharmacol., 194, 22-27. https://doi.org/10.1016/j.cbpc.2017.01.008

TOIVOLA, D. M., ERIKSSON, J. E., \& BRAUTIGAN, D. L. 1994. Identification of protein phosphatase $2 \mathrm{~A}$ as the primary target for microcystin-LR in rat liver homogenates. FEBS letters, 344(2-3), 175-180. https://doi.org/10.1016/0014-5793(94)00382-3

TOIVOLA, D. M., GOLDMAN, R.D., GARROD, D.R., ERIKSSON, J.E., 1997. Protein phosphatases maintain the organization and structural interactions of hepatic keratin intermediate filament. J. Cell Sci. 110, 23-33 https://doi.org/10.1242/jcs.110.1.23

VALBONESI, P., SARTOR, G., \& FABBRI, E. 2003. Characterization of cholinesterase activity in three bivalves inhabiting the North Adriatic sea and their possible use as sentinel organisms for biosurveillance programmes. Sci. Total Environ., 312(1-3), 79-88. https://doi.org/10.1016/S0048-9697(03)002274

VANDERPLOEG, H. A., LIEBIG, J. R., CARMICHAEL, W. W., AGY, M. A., JOHENGEN, T. H., FAHNENSTIEL, G. L., \& NALEPA, T. F. 2001. Zebra mussel (Dreissena polymorpha) selective filtration promoted toxic Microcystis blooms in Saginaw Bay (Lake Huron) and Lake Erie. Can. J. Fish. Aquat. Sci., 58(6), 1208-1221. https://doi.org/10.1139/f01-066

VASCONCELOS, V. M. 1999. Cyanobacterial toxins in Portugal: effects on aquatic animals and risk for human health. Braz. J. Med. Biol. Res., 32(3), 249-254. https://doi.org/10.1590/S0100879X1999000300001.

VASCONCELOS, V. M., WIEGAND, C., \& PFLUGMACHER, S. 2007. Dynamics of glutathione-S-transferases in Mytilus galloprovincialis exposed to toxic Microcystis aeruginosa cells, extracts and pure toxins. Toxicon, 50(6), 740-745. https://doi. org/10.1016/j.toxicon.2007.06.010

VON RUCKERT, G., CAMPOS, M. D. C. S., \& ROLLA, M. E. 2004. Alimentação de Limnoperna fortunei (Dunker 1857): taxas de filtração com ênfase ao uso de Cyanobacteria. Acta Sci. Biol. Sci, 26(4), 421-429. https://doi.org/10.4025/actascibiolsci. v26i4.1523

YU, Y., ZHANG, Q., LIU, G., DENG, Y., KANG, J., ZHANG, F., ... \& QIAN, H. 2021. Proteomic analysis of zebrafish brain damage induced by Microcystis aeruginosa bloom. Sci. Total Environ., 795, 148865. https://doi.org/10.1016/j.scitotenv.2021.148865

WANG, M., WANG, D., LIN, L., \& HONG, H. 2010. Protein profiles in zebrafish (Danio rerio) brains exposed to chronic microcystinLR. Chemosphere, 81(6), 716-724. https://doi.org/10.1016/j. chemosphere.2010.07.061

WHEELOCK, C. E., PHILliPS, B. M., ANDERSON, B. S., MILLER, J. L., MILLER, M. J., \& HAMMOCK, B. D. 2008. Applications of carboxylesterase activity in environmental monitoring and toxicity identification evaluations (TIEs). In Reviews of environmental contamination and toxicology ( $\mathrm{pp}$. 117-178). Springer, New York, NY.

WILLIAMS, D. E., DAWE, S. C., KENT, M. L., ANDERSEN, R. J., CRAIG, M., \& HOLMES, C. F. 1997. Bioaccumulation and clearance of microcystins from salt water mussels, Mytilus edulis, and in vivo evidence for covalently bound microcystins in mussel tissues. Toxicon, 11(35), 1617-1625. https://doi. org/10.1016/S0041-0101(97)00039-1

WU, Q., YAN, W., LIU, C., LI, L., YU, L., ZHAO, S., \& LI, G. 2016. Microcystin-LR exposure induces developmental neurotoxicity in zebrafish embryo. Environ. Pollut., 213, 793-800. https://doi. org/10.1016/j.envpol.2016.03.048. 